\title{
Hverfandi lungu - sjúkratilfelli
}

\author{
Pórunn Halldóra Pórðardóttir ${ }^{1}$ læknir, Árni Jón Geirsson ${ }^{2}$ læknir, Sif Hansdóttir ${ }^{3}$ æknir
}

\section{Á G I P}

55 ára kona með iktsýki var endurtekið lögð inn á Landspítalann vegna hita, mæði og takverks. Blóðprufur sýndu eðlileg hvít blóðkorn en hækkað CRP og sökk. Ræktanir reyndust neikvæðar. Myndrannsóknir af lungum sýndu pindarhástöðu, lungnavanpenslu (atelectasis) og fleiðruvökva beggja vegna en eðlilegan lungnavef. Öndunarpróf sýndu herpumynd. Anti-dsDNA og anti-Ro/SSA mótefni mældust hækkuð. Vaknaði grunur um heilkenni hverfandi lungna og lyfjaorsakađa rauða úlfa í kjölfar infliximabs. Sjúklingur fékk sterameðferð með góðum árangri, en versnaði jafnharðan aftur. Sjúklingur sýndi mikil batamerki eftir rituximab meðferð. Hér er tilfellinu lýst og greint frá sjaldgæfu birtingarformi rauðra úlfa sem ekki hefur verið lýst á Íslandi áđur.

\section{Inngangur}

Bandvefssjúkdómar eru oft erfiðir í greiningu og flokkun enda eru einkenni peirra margbreytileg. Meðferð samanstendur gjarnan af ónæmisbælandi lyfjum sem hafa ýmsar aukaverkanir en vegna ónæmisbælingar eru pessir sjúklingar útsettir fyrir sýkingum. Bandvefssjúkdómarnir sjálfir geta valdið hita og almennum slappleika og erfitt getur reynst að greina á milli versnunar á sjúkdómnum sjálfum, sýkinga og mögulegra aukaverkana lyfja. Við lýsum hér tilfelli með sjaldgæfu birtingarformi af lyfjaorsökuðum rauðum úlfum (drug induced lupus) sem reyndist erfitt að greina en svaraði vel meðferð pegar greining lá fyrir.

\section{Tilfelli}

55 ára gömul kona sem greindist með iktsýki með jákvæðan gigtarpátt (rheumatoid factor/RF) og anti-cyclic citrullinated peptide (CCP) mótefni sumarið 2014 (T0). Hún var í upphafi meðhöndluð með methotrexati og sterum, svaraði peirri meðferð vel í byrjun en versnaði síðan um hálfu ári síðar með útbreiddari og verri liðbólgum. Í lok ársins 2014 var pví hafin meðferð með infliximab (Remicade) auk methotrexats og prednisólóns (T0 + 6 mán.). Eftir hleðslugjöf eða prjá skammta af infliximab sem gefnir voru á 6 vikum veiktist hún skyndilega. Hún leitaði til gigtlæknis á göngudeild (T0 + 8 mánuðir) með nokkurra daga sögu um hita, hálssærindi, mæði við útaflegu og áreynslu og takverk vinstra megin. Enginn hósti eða uppgangur. Рað var engin fyrri saga um lungnasjúkdóma og hún hafði aldrei reykt. Við skoðun var hiti $38^{\circ} \mathrm{C}$, púls 106 slög/mín og súrefnismettun 95\% á andrúmslofti. Ekki roði eða skánir í koki. Lungnahlustun hrein. Blóðprufur sýndu eðlilegan heildarfjölda hvítra blóðkorna en hækkað CRP og sökk (tafla I). Lungnamynd sýndi lungnavanpenslu neðarlega hægra megin (mynd 1a). Í ljósi undirliggjandi ónæmisbælingar var gefin meðferð með stakri gjöf af ceftriaxone í æð og í framhaldinu amox-

'Lyflækningadeild, ${ }^{2}$ gigtardeild, ${ }^{3}$ lungnadeild Landspítala.

Fyrirspurnum svarar Pórunn Halldóra Pórðardóttir, thorhtho@landspitali.is

https://doi.org/10.17992//bl.2017.05.137

Grein barst blađinu 6. febrúar 2017, sampykkt til birtingar 21. apríl 2017. icillin og oseltamivir um munn. Gigtarpróf voru send og sýndu hækkun á RF og anti-CCP mótefnum, eins og dæmigert er hjá sjúklingum með iktsýki. Hins vegar reyndist einnig vera hækkun á kjarnamótefnum (anti-nuclear antibody/ANA), anti-dsDNA og anti-Ro sem gjarnan hækka í rauðum úlfum (tafla I). Tíu dögum eftir komu á göngudeild leitaði konan á bráðamóttöku Landspítalans með versnandi einkenni. Lífsmörk við komu voru hiti $39,9^{\circ} \mathrm{C}$, púls 111 slög/mín, blóðprýstingur 101/48mmHg, öndunartíðni $24 /$ mín og súrefnismettun $88 \%$ á andrúmslofti. Við skoðun var hún mjög slöpp að sjá. Ekkert athugavert var að sjá í munni og koki og ekki preifuðust eitlastækkanir. Við lungnaskoðun var bankdeyfa neðarlega vinstra megin, grunn innöndun og minnkuð öndunarhljóð beggja vegna ásamt vægu brakhljóði neðan til vinstra megin. Tekin var röntgenmynd af lungum (mynd $1 b$ ) sem sýndi vaxandi lungnavanpenslu og nú einnig fleiðruvökva beggja vegna. Blóðprufur sýndu áfram eðlilegan fjölda hvítra blóðkorna en hækkandi CRP (tafla I). Hún lagðist inn á sjúkrahús par sem gefin var meðferð með súrefni í nös, ceftriaxone í æð og azithromycin um munn vegna gruns um lungnabólgu og mögulega sýklasótt. Methotrexat var stöðvað tímabundið en gefinn streituskammtur af sterum með hydrocortisone í æð og í framhaldi af pví prednisólón. Næstu daga var sjúklingurinn áfram með háan hita, mikla mæði, takverk og öndunarbilun sem parfnaðist súrefnisgjafar. Hún var með auknar liðbólgur í höndum, hnjám og vinstri ökkla. Blóðprufur á meðferð sýndu lækkandi CRP og sökk. Allar ræktanir voru neikvæðar (blóð, hráki, háls- og nefkoksstrok, pvag). Gerð var tölvusneiðmynd af lungum sem sýndi fleiðruvökva beggja vegna, lungnavanpenslu en eðlilega útlítandi lungnavef (mynd 2). Í framhaldi var gerð fleiðruástunga vinstra megin og fjarlægðir um 50 $\mathrm{ml}$ af ljósgulum og tærum fleiðruvökva sem reyndist vera útvessi (transudate) skv. skilmerkjum Lights (fleiðru/sermi próteinhlutfall var 0,42 og LDH hlutfall 0,41). Sýrustig (pH) vökvans var 7,6. Ræktanir á fleiðruvökva voru neikvæðar fyrir bakteríum, sveppum og sýruföstum stöfum. Hjartaómun sýndi væga hlébilsbilun en NTproBNP var innan eðlilegra marka. Sjúklingur fékk meðferð með sýklalyfjum í samtals 12 daga. Pegar ljóst pótti að ekki var um að ræða sýkingu voru einkenni talin stafa af versnun á iktsýki og steraskammtar hækkaðir. Gigtarpróf voru endurtekin í legu (tafla I) og voru svipuð og við komu á göngudeild fyrir innlögn. Sjúklingurinn fékk greininguna fleiðrubólga af óljósri orsök. Hún jafnaði sig smám saman í 6 vikna legu á háum skömmtum af sterum 
Tafla I. Blóðprufur; hvít blóðkorn, bólgumiðlar og gigtarpróf.

\begin{tabular}{|c|c|c|c|c|}
\hline $\begin{array}{l}\text { Blóðrannsóknir (eðlileg } \\
\text { viðmið) }\end{array}$ & $\begin{array}{c}\text { Koma á } \\
\text { göngudeild } \\
\text { (T0 + } 8 \\
\text { mán.) }\end{array}$ & $\begin{array}{c}\text { Innlögn } \\
\# 1 \text { (T0 + } \\
\text { 8,5 mán.) }\end{array}$ & $\begin{array}{c}\text { Innlögn \#3 } \\
\text { (T0 + } 14 \\
\text { mán.) }\end{array}$ & $\begin{array}{c}\text { Eftirlit } \\
(\text { TO + } 31 \\
\text { mán.) }\end{array}$ \\
\hline Hbk (4,0-10,5 x10E9/L) & 7,5 & 5,7 & 5,7 & 6,9 \\
\hline Sökk (<23 mm/klst) & 38 & $\ldots$ & 64 & 22 \\
\hline CRP (<10 mg/L) & 43 & 104 & 62 & 10 \\
\hline $\operatorname{RF}(<1: 40)$ & $1: 160$ & $\ldots$ & $\ldots$ & \\
\hline RF ELÍSA (<4 U/mL) & 30 & $\ldots$ & 21 & \\
\hline Anti-CCP $(<25 \mathrm{U} / \mathrm{mL})$ & 36 & $\ldots$ & $<25$ & \\
\hline ANA $(<1: 40)$ & $>1: 300$ & $>1: 300$ & $>1: 300$ & \\
\hline ENA ( $<1,0$ ein) & 6,1 & 6,2 & 6,5 & \\
\hline Anti-dsDNA (<10 IU/mL) & 43 & 13 & 55 & \\
\hline Anti-Ro/SSA ( $<1,0$ ein) & 3,9 & 3,1 & 4,2 & \\
\hline CH50 (60-124\%) & $\ldots$ & 60 & 50 & \\
\hline C3 $(0,74-1,38 \mathrm{~g} / \mathrm{L})$ & $\ldots$ & 1,11 & 0,93 & \\
\hline C4 $(0,14-0,37 \mathrm{~g} / \mathrm{L})$ & $\ldots$ & 0,16 & 0,13 & \\
\hline
\end{tabular}

Hbk = hvít blóðkorn. $\mathrm{CRP}=\mathrm{C}$-reactive protein. $\mathrm{RF}=$ rheumatoid factor/gigtarpáttur. Anti-CCP $=$ anti-citrullinated protein antibody. ANA $=$ anti-nuclear antibody/

kjarnamótefni. ENA = extractable nuclear antigen antibody. Anti-dsDNA $=$ anti-double stranded DNA. $\mathrm{CH} 50=$ heildar komplement-virkni. $\mathrm{C} 3=$ complement component $3 /$ komplement 3. $\mathrm{C} 4=$ complement component $4 /$ komplement 4 .

T0 = fyrsta skoðun, tími núll.

sem trappaðir voru niður og útskrifaðist heim á methotrexat og prednisólón.

Sjúklingur lagðist inn í prígang næstu mánuði með sömu einkenni, pað er hita, mæði og takverk. Einkenni versnuðu í hvert skipti sem steraskammtar voru minnkaðir. Endurteknar blóðprufur sýndu eðlileg hvít blóðkorn en hækkun á sökki og CRP (tafla I). Myndrannsóknir af lungum sýndu grunna innöndun, fleiðruvökva beggja vegna og lungnavanpenslu neðan til í báðum lungum (mynd 1c). Öndunarpróf voru gerð og sýndu herpumynd með minnkuðum lungnarúmmálum og lækkun á loftdreifiprófi (tafla II). Framkvæmd var berkjuspeglun sem sýndi að stóru berkjurnar voru vel opnar, eðlilega slímhúð og enga slímtappa. Allar ræktanir voru neikvæðar. Gigtarpróf voru endurtekin í priðju legu (tafla I) og var pá anti-CCP innan marka en RF, ANA, anti-dsDNA og antiRo áfram hækkuð. Sjúklingur fékk í pessum legum meðferð með
Tafla II. Öndunarpróf

\begin{tabular}{lccc}
\hline Öndunarpróf & $\begin{array}{c}\text { Innlögn \#2 } \\
\text { (T0 + } 10 \text { mán.) }\end{array}$ & $\begin{array}{c}\text { Innlögn \#3 (T0 } \\
+14 \text { mán.) }\end{array}$ & $\begin{array}{c}\text { Eftirlit (T0 + } \\
31 \text { mán.) }\end{array}$ \\
\hline FVC, L (\% af áætluðu) & $1,19(36)$ & $1,33(40)$ & $2,03(62)$ \\
\hline FEV1, L (\% af áætluðu) & $0,99(38)$ & $1,09(42)$ & $1,54(60)$ \\
\hline FEV1/FVC & 0,83 & 0,82 & 0,76 \\
\hline TLC, L (\% af áætluðu) & $2,18(46)$ & & \\
\hline RV, L (\% af áætluðu) & $1,0(57)$ & & 58 \\
\hline DLCOc, \% af áætluðu & 44 & 45 &
\end{tabular}

FVC = forced vital capacity (heildarfrámál). FEV1 $=$ forced expiratory volume in one second (fráblástur á fyrstu sekúndu útöndunar). TLC = total lung capacity (heildarbangeta lungna). RV = residual volume (loftleif). DLCO = diffusing capacity for (heildarpangeta lungna). $\mathrm{RV}=$ resid

háum skömmtum af sterum og á peirri meðferð lagaðist mæðin og hún varð hitalaus en takverkurinn var áfram til staðar.

Við eftirfylgd á göngudeild hjá gigtlækni og lungnalækni eftir priðju sjúkrahúslegu voru sjúkdómsgangur og rannsóknarniðurstöður endurskoðaðar. Sjúklingur hafði upphaflega veikst með illvígri fjölliðabólgu í smáum og stórum útlimaliðum, dæmigert fyrir iktsýki. Hún reyndist hafa jákvæðan gigtarpátt af IgM gerð og væga hækkun á CCP mótefnum en kjarnamótefni höfðu ekki verið mæld í byrjun sjúkdómsins. Sjúklingur svaraði upphaflega vel meðferð með methotrexat og sterum en versnaði hálfu ári síðar og pá var hafin meðferð með infliximab. Eftir prjá lyfjaskammta pegar búast hefði mátt við bata breyttist sjúkdómsmyndin og sjúklingi versnaði skyndilega með svæsnum lungnaeinkennum eins og lýst er að ofan. Hún fékk lungnavanpenslu og fleiðruvökva beggja vegna, lungnarúmmál voru smækkuð og öndunarpróf staðfestu herpu en lungnavefur var eðlilegur og engin merki um trefjavefslungnabólgu (interstitial lung disease). Starfsemi pindarinnar var metin með skyggningu á pind, Sniff-rannsókn (diaphragm fluoroscopy), hún hreyfðist samhverft og ekki sáust nein merki um pindarlömun. Pá var framkvæmt svonefnt MIP-próf (maximal inspiratory pressure) sem endurspeglar styrk pindarinnar og annarra innöndunarvöðva og reyndist sú rannsókn vera eðlileg. Endurtekin gigtarpróf bentu frekar til rauðra úlfa en iktsýki með háum títer af ANA, jákvæðu anti-dsDNA, jákvæðu anti-SSA og minnkaða virkni komplement-kerfisins (lækkað CH50 og C4) (tafla 1). Anti-CCP fór aftur á móti úr pví að vera jákvætt yfir í að vera neikvætt. Anti-histón mótefni voru neikvæð. Sjúklingi batn-
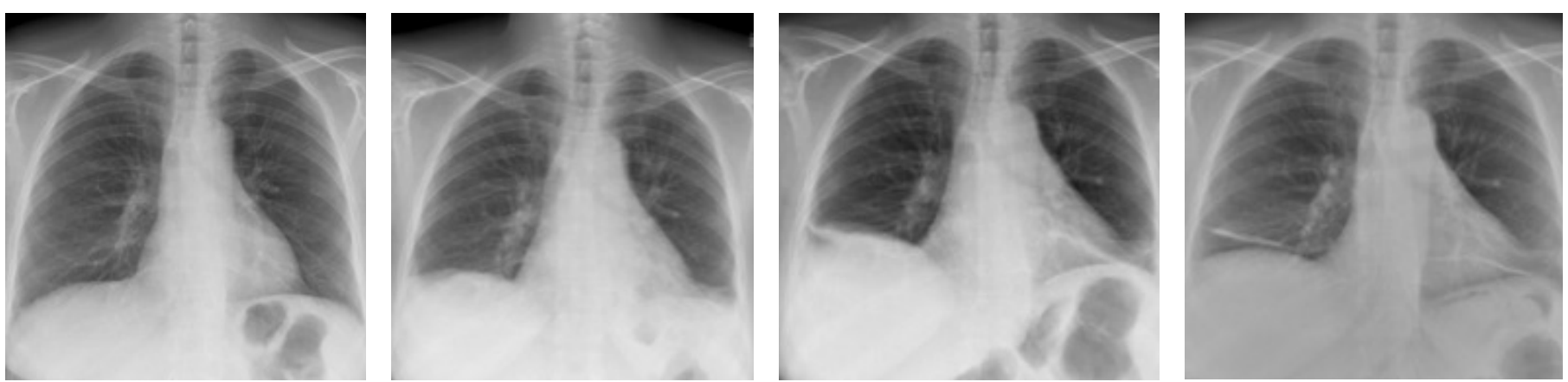

Mynd 1. Röntgenmyndir af lungum. a) Koma á göngudeild (T0 + 8 mánuðir): Lungnavanpensla (atelectasis) neðarlega hægra megin en að öðru leyti hrein lungnamynd. b) Fyrstainnlögn (10 dögum eftir komu á göngudeild): Grynnri innöndun. Fleiðruvökvi beggja vegna og íferð neðan til vinstra megin. c) Priðja innlögn (T0 + 14 mánuðir): Grunn innöndun, afmarkað vökvasafn í hægra lunga og vægur fleiðruvökvi vinstra megin. Á myndum b) og c) sést glögglega hve smækkuð lungun eru í samanburði við fyrstu myndina. d) Eftirlit (T0 + 31 mánuðir). Grunn innöndun en batnandi. Minni lungnavanpensla og enginn fleiðruvökvi. 

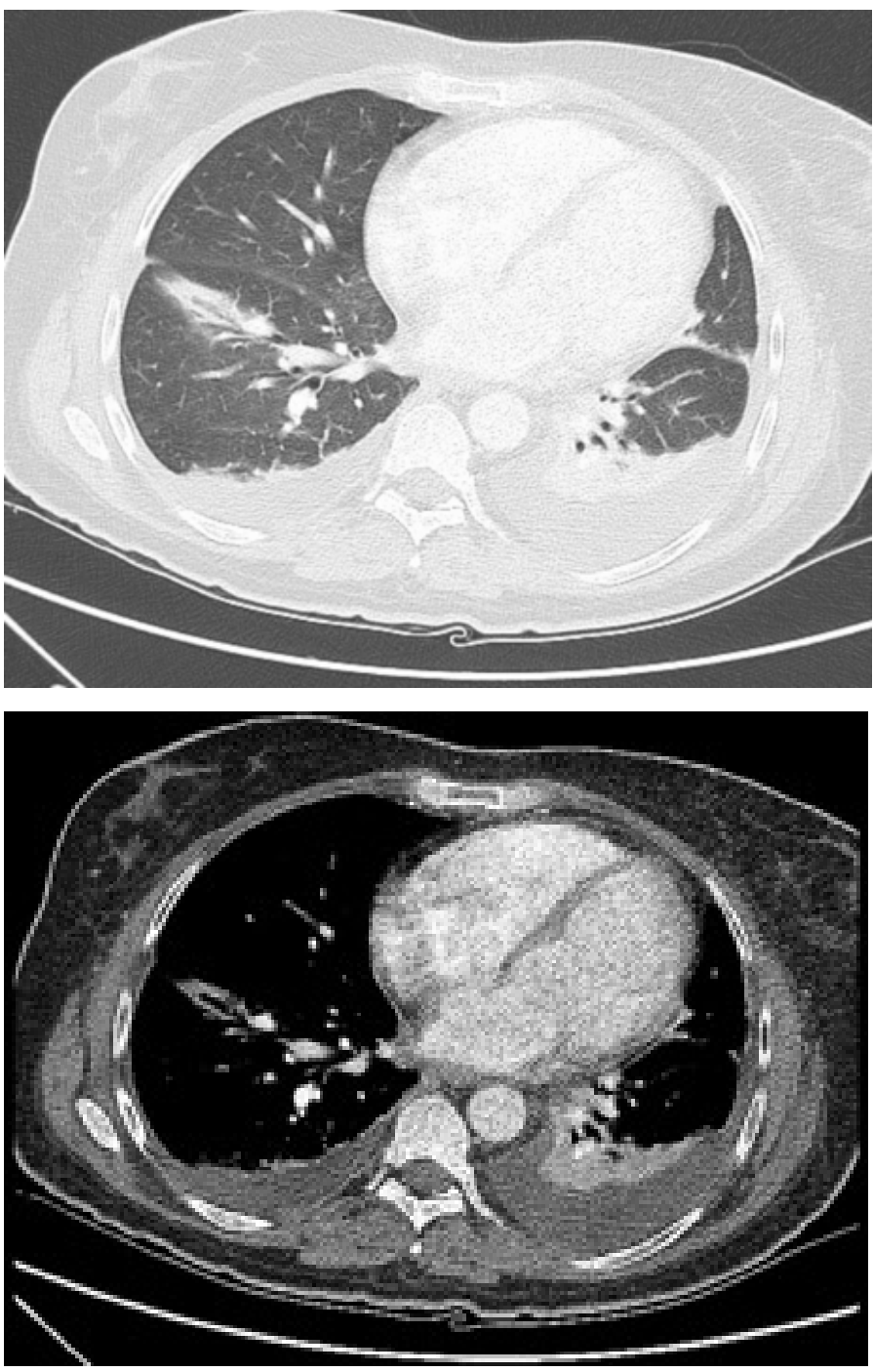

Mynd 2. Tölvusneiðmynd af lungum tekin snemma í fyrstu legu: Samfall á lungum neðan til og fleiðruvökvi beggja vegna, $2 \mathrm{~cm}$ hægra megin og $3 \mathrm{~cm}$ vinstra megin. Ekki sáust eitlastækkanir né æxlisgrunsamlegar breytingar og lungnavefur var að öðru leyti eðlilega útlítandi.

aði við sterameðferð en versnaði jafnóðum pegar steraskammtar voru minnkaðir. Í ljósi ofangreinds var talið líklegast sjúklingur hefði fengið lyfjaorsakaða rauða úlfa af völdum infliximab eða svokallaða anti-TNF framkallaða rauða úlfa og í ljósi peirrar greiningar og pess að áberandi var hve lungun höfðu smækkað vaknaði grunur um „hverfandi lungu“ eða svokallað „,shrinking lung syndrome" (SLS).

Í kjölfarið var ákveðið var að hefja meðferð með rituximab (T0 + 21 mánuðir), lyfi sem er sérhæft líftæknilyf og einstofna mótefni gegn CD20 jákvæðum B-eitilfrumum. Lyfið fækkar B-eitilfrumum og afleiðum peirra, plasmafrumum sem eru taldar meinvaldurinn í rauðum úlfum, og hefur einnig verið notað við „hverfandi lungum“. Rituximab var gefið í tvígang næstu vikurnar með mjög góðri svörun. Við eftirlit fjórum mánuðum síðar (T0 + 25 mánuðir) var líðan sjúklings almennt mjög góð, hún var orðin vinnufær á ný eftir margra mánaða fjarveru frá vinnu, liðbólgur höfðu gengið niður og lungnaeinkenni voru verulega batnandi. Mæði var ekki lengur til staðar í hvíld en kom fram við áreynslu, af og til fann hún fyrir takverk hægra megin en var hitalaus og súrefnismettun var $98 \%$ á andrúmslofti. Innöndun var dýpri en áđur og lungnahlustun hrein. Hún sýndi enn frekari batamerki á næstu mánuðum. Við síðasta endurmat (T0 + 31 mánuður) voru bólgupróf (sökk og CRP)
Tafla III. Tímalína veikinda.

\begin{tabular}{lll}
\hline Tímasetning & Veikindi & Meðferð \\
\hline T0 & Greining iktsýki & $\begin{array}{l}\text { Methotrexat og } \\
\text { prednisólón }\end{array}$ \\
\hline T0 + 6 mán. & Versnun liðeinkenna & $\begin{array}{l}\text { Infliximab (Remicade) } \\
\text { bætt við }\end{array}$ \\
\hline T0 + 8-20 mán. & $\begin{array}{l}\text { Bráð veikindi - hiti og } \\
\text { lungnaeinkenni auk liðeinkenna }\end{array}$ & $\begin{array}{l}\text { Endurteknar innlagnir } \\
\text { ánu ári, ítarleg } \\
\text { uppvinnsla og meðferð } \\
\text { með sýklalyfjum og } \\
\text { sterum }\end{array}$ \\
\hline T0 + 21 mán. & $\begin{array}{l}\text { Greining á lyfjaorsökuðum } \\
\text { rauðum úlfum og hverfandi } \\
\text { lungum }\end{array}$ & $\begin{array}{l}\text { Hafin meðferð með } \\
\text { rituximab (Rituxan) }\end{array}$ \\
\hline T0 + 25 mán. & $\begin{array}{l}\text { Eftirlit, mun betri líðan, komin } \\
\text { til vinnu }\end{array}$ & Óbreytt meðferð \\
\hline T0 + 31 mán. & $\begin{array}{l}\text { Síðasta eftirlit, áfram batnandi, } \\
\text { engar frekari innlagnir }\end{array}$ & Óbreytt meðferð \\
\hline
\end{tabular}

eðlileg (tafla I), röntgenmynd af lungum batnandi (mynd 1d) og öndunarpróf sýndu umtalsvert minni herpu og heildarfrámál (forced vital capacity/ FVC) hafði nánast tvöfaldast (tafla II). Yfirlit yfir tímalínu veikinda má sjá í töflu III.

\section{Umræða}

Heilkenni „hverfandi lungna“ var fyrst lýst árið 1965 par sem skýrt var frá 8 tilfellum sjúklinga með rauða úlfa sem höfðu vaxandi óútskýrða mæði og herpumynd á fráblástursprófi ásamt smækkandi lungnarúmmálum á lungnamynd. Par sem lungun virtust beinlínis vera að hverfa fyrir augum peirra leiddi pað til pessarar lýsandi nafngiftar. ${ }^{1}$ Lungnasjúkdómar eru ekki óalgengir í rauðum úlfum og sjást hjá um 40-80\% sjúklinga. Lungnavandamálin eru mjög fjölbreytt og geta verið allt frá bólgu í fleiðru og/ eða lungnavef yfir í trefjavefslungnabólgu og lungnaháprýsting. ${ }^{2,4}$ Hverfandi lungu eru sjaldgæft birtingarform og algengi verið talið um 0,5-6\% hjá sjúklingum með rauða úlfa. ${ }^{1}$ Meðalaldur við greiningu er um 35-40 ár og hlutfall kvenna á móti körlum er talið 6:1. ${ }^{2}$ prátt fyrir að sjást fyrst og fremst í rauðum úlfum hefur einstaka tilfellum verið lýst í öðrum bandvefs- og gigtsjúkdómum, svo sem Sjögrens, iktsýki, herslismeini (scleroderma) og fjölvöðvabólgu (polymyositis).,3 Í nýrri yfirlitsgrein voru tekin saman pau tilfelli sem birt hafa verið og eru pau 155 að tölu. ${ }^{4}$ Ekki er vitað til pess að sjúkdómsmyndin hafi áđur greinst á Íslandi og ekki er vitað til pess að hún hafi sést í lyfjaorsökuðum rauðum úlfum áður.

Formleg skilmerki hafa ekki verið sett fram en grunsemdir um sjúkdóminn ættu að vakna hjá meðferðaraðilum ef sjúklingur með gigtsjúkdóm fær óútskýrða vaxandi mæði ásamt takverk og rannsóknir leiða í ljós herpumynd á fráblástursprófi og smækkuð lungnarúmmál en alveg eðlilegan lungnavef og fleiðrur á tölvusneiðmynd. Myndrannsóknir af lungum geta jafnframt sýnt pindarhástöðu, samfall á lungnavef og fleiðruvökva., Jákvætt ANA mótefni er alltaf til staðar ásamt hækkuðu sökki. ${ }^{2}$ Önnur gigtarpróf geta stutt við greiningu en lýst hefur verið sambandi milli hækkaðs anti-Ro/SSA mótefnis og hverfandi lungna en mótefnið reyndist einmitt hækkað í umræddu tilfelli. ${ }^{2-4}$ Orsakir 
eru ekki með fullu pekktar og meinalífeðlisfræðin á bakvið sjúkdómsmyndina er ekki nákvæmlega skilgreind. Ýmsum vangaveltum hefur verið varpað fram, pá helst um einhvers konar bólgu í pindarvöðvum (myositis, myopathy) sem leiðir til pindarhástöðu og vanstarfsemi, eða langvarandi bólgu í fleiðru sem virkjar verkjareflexa og truflar djúpa innöndun. Smám saman minnkar pan lungna og vítahringur myndast. Aðrar kenningar hafa verið settar fram um mögulegan skort á lungnablöðruseyti (surfactant) með meðfylgjandi samfalli í lungnablöðrum (upphafleg kenning Hoffbrand og Beck), taugamein í n. phrenicus, almennt máttleysi í innöndunarvöðvum eða einhvers konar óútskýrða truflun í brjóstveggnum. $^{3-6}$ Í peim tilfellum sem lýst hefur verið hefur sterameðferð reynst gagnleg (prednisólón 20-80 mg/dag) en nýlegri rannsóknir sýna fram á gagnsemi rituximab (anti-CD20 mótefni). Ýmis önnur lyf notuð við rauðum úlfum, svo sem hydroxychloroqín, cyclofosfamíð og azathioprín hafa gefið misgóðan árangur. ${ }^{3,4,5,8}$ Samfara sterameðferð hafa verið reynd bæði theofyllín, sem talið er auka styrk pindarinnar, og $\beta$-2-örvandi lyf, sem minnka preytu í pind í gegnum jákvæð samdráttarhvetjandi (jónótróp) áhrif, og hvort tveggja gefið ágætis árangur. ${ }^{4}$ Tilfelli petta sýnir glögglega hve mikilvægt er að pekkja pessa sjúkdómsmynd pó sjaldgæf sé og kunna að beita réttri meðferð, ella er hætta á áframhaldandi framgangi sjúkdómsins með umtalsverðri skerðingu á lífsgæðum. Svo framarlega sem réttri meðferð er beitt eru horfur pessa heil- kennis að öllu jöfnu góðar, lungnarúmmál geta orðið eðlileg og skerðing í fráblæstri getur gengið að mestu leyti til baka. ${ }^{3,4,7}$

Infliximab er vel pekkt fyrir að leiða til myndunar á ANA og anti-dsDNA mótefnum hjá sjúklingum með iktsýki en afar sjaldan veldur pað einkennum og klárir lyfjaorsakaðir rauðir úlfar eru sjaldséðir. ${ }^{9-11}$ Orsökin fyrir pessu er ekki pekkt. Lyfjaorsakaðir rauðir úlfar af völdum anti-TNF-alpha hemja (anti-TNF-induced lupus/ ATIL) á borð við infliximab eru frábrugðnir lyfjaorsökuðum rauðum úlfum af öðrum toga (drug-induced lupus/ DIL) að pví leytinu til að í DIL eru ANA og anti-histón mótefni mjög oft jákvæð (í annars vegar $>99 \%$ og hins vegar $>95 \%$ tilfella) en anti-dsDNA mótefni hins vegar yfirleitt neikvæð ( $<1 \%$ jákv). Í ATIL hins vegar sjást anti-histón mótefni yfirleitt ekki en anti-dsDNA mótefni eru jákvæð í >90\% tilfella. Jákvætt ENA og lækkun á komplementum sjást einnig oftar í ATIL, rétt eins og í ofanlýstu tilfelli. ${ }^{12}$ Skilmerki sem parf að uppfylla fyrir greiningu á lyfja-lupus eru fjögur af peim 11 skilmerkjum sem sett hafa verið fram af American College of Rheumatology ásamt pví að sjúklingur sé samhliða útsettur fyrir lyfi sem pekkt er fyrir að valda sjúkdómnum. ${ }^{12,13}$ ATIL er yfirleitt sjálftakmarkandi og gengur yfir pegar framkallandi páttur er fjarlægður en pekkt dæmi eru um meira langvarandi einkenni og yfirleitt er pörf á einkennameðferð með sterum eða öðrum ónæmisbælandi lyfjum á borð við rituximab. ${ }^{12,14}$

\section{Heimildir}

1. Munoz ML, Gelber AC, Houston BA. Into Thin Air: Shrinking Lung Syndrome. Am J Med 2014; 127: 711-3.

2. Singh R, Huang W, Menon Y, Espinoza LR. Shrinking lung syndrome in systemic lupus erythematosus and Sjogren's syndrome. J Clin Rheumatol 2002; 8: 340-5.

3. Hemmati I, Blocka K. Shrinking lung syndrome masked by pleuropericarditis: a case report and review of the literature. Clin Rheumatol 2012; 31: 1741-4.

4. Duron L, Cohen-Aubart F, Diot E, Borie R, Abad S, Richez C, et al. Shrinking lung syndrome associated with systemic lupus erythematosus: A multicenter collaborative study of 15 new cases and a review of the 155 cases in the literature focusing on treatment response and long-term outcomes. Autoimmun Rev 2016; 15: 994-1000.
5. Toya SP, Tzelepis GE. Association of the shrinking lung syndrome in systemic lupus erythematosus with pleurisy: a systematic review. Semin Arthristis Rheum 2009; 39: 30-7.

6. Henderson LA, Loring SH, Gill RR, Liao KP, Ishizawar R, Kim S, et al. Shrinking lung syndrome as a manifestation of pleuritis: a new model based on pulmonary physiological studies. Rheumatol 2013; 40: 273-81.

7. Pillai $\mathrm{S}$, Mehta $\mathrm{J}$, Levin $\mathrm{T}$, Muzumdar $\mathrm{H}$, Nandalike K. Shrinking lung syndrome presenting as an initial pulmonary manifestation of SLE. Lupus 2014; 23: 1201-3.

8. Langenskjöld E, Bonetti A, Fitting JW, Heinzer R, Dudler J, Spertini $F$, et al. Shrinking lung syndrome successfully treated with rituximab and cyclophosphamide. Respiration 2012; 84: 144-9.
9. Benucci M, Li Gobbi F, Fossi F, Manfredi M, Del Rosso A. Drug-induced lupus after treatment with infliximab in rheumatoid arthritis. J Clin Rheumatol 2005; 11: 47-9.

10. Louis M, Rauch J, Armstrong M, Fitzcharles MA. Induction of autoantibodies during prolonged treatment with infliximab. J Rheumatol 2003; 30: 2557-62.

11. pneumotox.com/effect/view/454/infliximab/V.d/pleuralpericardial-effusion-ana-positive-di-lupus/ - apríl 2017.

12. Williams EL, Gadola S, Edwards CJ. Anti-TNF-induced lupus. Rheumatology 2009; 48: 716-20.

13. rheumatology.org/Practice-Quality/Clinical-Support/ Criteria/ACR-Endorsed-Criteria - janúar 2017.

14. De Bandt M, Sibilia J, Le Loet X, Prouzeau S, Fautrel B, Marcelli C, et al. Systemic lupus erythematosus induced by anti-tumor necrosis factor alpha therapy: a French national survey. Arthritis Res Ther 2005; 7: R545-51.

\section{ENGLISH SUMMARY}

\section{Vanishing lungs - a case report}

Pórunn Halldóra Pórðardóttir ${ }^{1}$, Árni Jón Geirsson², Sif Hansdóttir ${ }^{3}$

A 55 year old female with rheumatoid arthritis who was repeatedly admitted to internal medicine for fever, shortness of breath and pleuritic chest pain. Laboratory work up showed normal WBC but elevated CRP and sedimentatation rate. Cultures were negative. Imaging studies revealed elevated diaphragms, bilateral atelectasis and pleural fluid but normal lung parenchyma. Lung function testing showed restrict- ion. Anti-dsDNA and anti-Ro/SSA were elevated. A clinical diagnosis of anti-TNF-induced lupus secondary to infliximab and shrinking lung syndrome was made. The patient showed improvement on steroids but subsequent worsening when tapered. Rituximab was then initiated with good results.

'Department of Internal Medicine, ${ }^{2}$ Department of Rheumatology, ${ }^{3}$ Department of Respiratory Medicine, Landspitali University Hospital.

Key words: rheumatoid arthritis, infliximab, restrictive lung disease, shrinking lung syndrome, anti-TNF induced lupus.

Correspondence: Pórunn Halldóra Pórðardóttir, thorhtho@landspitali.is 